\title{
46,XY gonadal dysgenesis-motor and sensory neuropathy syndrome
}

INSERM

\section{Source}

INSERM. (1999). Orphanet: an online rare disease and orphan drug data base. $\underline{46, X Y}$ gonadal dysgenesis-motor and sensory neuropathy syndrome. ORPHA:168563

$46, \mathrm{XY}$ gonadal dysgenesis-motor and sensory neuropathy syndrome is a rare, genetic, developmental defect during embryogenesis disorder characterized by partial (unilateral testis, persistence of Müllerian duct structures) or complete (streak gonads only) gonadal dysgenesis, usually manifesting with primary amenorrhea in individuals with female phenotype but 46,XY karyotype, and sensorimotor dysmyelinating minifascicular polyneuropathy, which presents with numbness, weakness, exercise-induced muscle cramps, sensory disturbances and reduced/absent deep tendon reflexes. Germ cell tumors (seminoma, dysgerminoma, gonadoblastoma) may develop from the gonadal tissue. 